Omni-Akuatika Special Issue 3rd Kripik SCiFiMaS 2020: 42 - 48
ISSN: 1858-3873 print / 2476-9347 online
Research Article
journal homepage: http://ojs.omniakuatika.net

\title{
Comparison of Simulated and Observed Current Velocities in Karimata and Gaspar Straits
}

\author{
Mukti Trenggono $^{1 *}$, Bayu Priyono ${ }^{2}$, Rizqi Rizaldi Hidayat ${ }^{1}$, Teguh Agustiadi $^{2}$ \\ 1.Fisheries and Marine Science Faculty, Jenderal Soedirman University, Jl. Dr. Suparno, \\ Karangwangkal, Purwokerto 53123, Indonesia \\ 2.Institute for Marine Research and Observation, Ministry of Marine Affairs and Fisheries, Jl. Baru Perancak, \\ Jembrana, Bali, 82251, Indonesia \\ ${ }^{\star}$ Corresponding author, e-mail: mukti.trenggono@unsoed.ac.id
}

Received 20 November 2019; Accepted 1 October 2020; Available online 31 December 2020

\begin{abstract}
Karimata and Gaspar Straits were the connector between the South China Sea and Indonesian Seas, which played a role in transporting the Indonesian Through Flow. The current velocities in both straits were studied by comparing outputs from the INDO12 physical ocean model simulation against observation results from the South China Sea-Indonesian Seas Transport Exchange (SITE) program. In general, the magnitudes of the zonal and meridional model current velocities are weaker than observations. Notably, the B1 and B4 moorings show uncertain model values most of the time. It is understandable considering that B1 and B4 moorings are located in a narrow strait (Gaspar Strait), near the coasts. On the contrary, B2 and B3 moorings show comparable magnitude to the two zonal and meridional components' observations
\end{abstract}

Keywords: Karimata Strait, Current Velocities, INDO12, SITE Program.

\begin{abstract}
ABSTRAK
Selat Karimata dan Gaspar adalah penghubung antara Laut Cina Selatan dan Laut Indonesia, berperan dalam pengangkutan Arus Lintas Indonesia. Kecepatan arus di kedua selat tersebut dipelajari dengan membandingkan keluaran simulasi model fisik samudra INDO12 dengan hasil pengamatan dari program South China Sea-Indonesian Seas Transport Exchange (SITE). Secara umum, besaran kecepatan arus model zonal dan meridional lebih lemah dari pengamatan. Khususnya, mooring B1 dan B4 menunjukkan nilai model yang tidak pasti hampir sepanjang waktu. Hal ini dapat dimaklumi mengingat mooring B1 dan B4 berada di selat sempit (Selat Gaspar), dekat pantai. Sebaliknya, mooring B2 dan B3 menunjukkan besaran yang sebanding dengan pengamatan dua komponen zonal dan meridional.
\end{abstract}

Kata kunci: Selat Karimata, kecepatan arus, INDO12, Program SITE

\section{Introduction}

The South China Sea (SCS) is one of the most massive marginal seas globally, and the Indonesian seas (ISS) constitute a significant passage linking the Pacific and Indian oceans (Fang et al., 2010). The SCS and ISS are connected through the Karimata Strait (KS) (Wei et al., 2016; Wang et al., 2019) and Gaspar Strait (Wang et al., 2019). Several numerical studies have revealed that the circulations in SCS and ISs are closely linked mainly through the KS [Metzger and Hurlburt, 1996; Lebedev and Yaremchuk, 2000; Fang et al., 2009; Tozuka et al., 2009; Yaremchuk et al., 2009] including the
Gaspar Strait. Karimata Strait separates Belitung Island and Kalimantan Island with a $220 \mathrm{~km}$ width and a depth of 18-50 m (Wang et al., 2019). The Gaspar Strait is located between Bangka Island and Belitung Island, width is approximately half that of the KS, and the depth is shallower than $30 \mathrm{~m}$ (Wang et al., 2019). Further knowledge of Karimata Strait's characteristics will help understand the regional and local ocean circulation and climate processes (Tozuka et al., 2009) because KS is an integral part of SCS. The annual average transport through Karimata Strait contributes to ITF transportation of around $13 \%$ (He et al., 2015). 


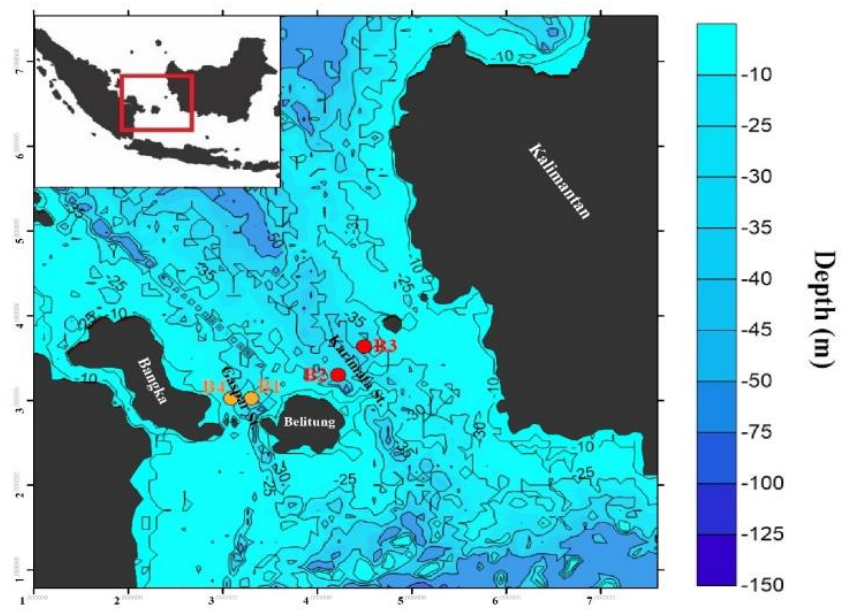

Figure 1. Trawl-Resistant Bottom-Mounted (TRBM) Moorings in Karimata Strait (B2 And B3) And in Gaspar Strait (B1 And B4). The Geographical Coordinates Are B1 $=2^{\circ} 34.6238^{\prime} \mathrm{S} ; 1^{\circ} 7^{\circ} 15.0331^{\prime} \mathrm{E} ; \mathrm{B}^{\circ}=2^{\circ}$ 16.6865' $^{\prime}$ S; $108^{\circ} 14.8359^{\prime} \mathrm{E}$; B3 = $1^{\circ} 54.6177^{\prime} \mathrm{S}$; $108^{\circ} 32.7034^{\prime} \mathrm{E}$; B4 = $2^{\circ} 34.6810^{\prime} \mathrm{S} ; 1^{\circ} 7^{\circ} 0.8997^{\prime} \mathrm{E}$. The Dataset Provided by SITE Project.

One of the providers ISs forecasting characteristics, including Karimata and Gaspar Strait, is an INDESO (Infrastructure Development of Space Oceanography) Project operational simulation. In the scope of the INDESO Project, a regional configuration of the OPA/NEMO global ocean circulation model has been implemented and adjusted in the ISS region. The physical design is fully operational since September 2014, called the INDO12 V1 configuration. Since the operational launch, the model was still improved by CLS and MercatorOcean. The new version INDO12 V1.1 is to be applied for the INDESO working system since March 2016. The two versions of INDO12 are a $1 / 12^{\circ}$ regional version of the NEMO physical ocean model covering the whole Indonesian Exclusive Economic Zone (Tranchant et al., 2016).

Validate the model results that remain highly required for many downstream applications (services or scientific studies). To improve the model quality, we have decided to focus on the Karimata and Gaspar Strait. We are comparing the model data from the INDO12 physical ocean model to in-situ observations gathered by the SITE research project (SCS and ISs Transport/Exchange) established jointly by the scientists from Indonesia, China, the United States. The SITE project aims to measure and analyze water masses' magnitude and variability and heat transport from SCS to Indonesian waters. Four trawl-resistant bottom-mounted (TRBM) Acoustic Doppler Current Profiler (ADCP) has been deployed in the Karimata Strait. Model velocities were compared to these observations.

\section{Materials and Methods}

Several observed datasets were used to validate the model. INDO model velocities were compared to observed velocities profiles obtained from ADCPs measurement. Positions of the four-trawl resistance bottom-mounted ADCP is shown in Figure 1. Two trawl-resistant bottom mounts (TRBMs) were deployed along Gaspar Strait (B1 and B4), and the current data were successfully obtained for almost two years. Two remains were deployed along Karimata Strait (B2 and B3).

In addition to the qualitative analysis, some quantitative analysis has also been carried out for validation. The Cost Function (CF) is a nondimensional value that quantifies the difference between the model values and observation data, thus indicating the goodness of fit between the two datasets (OSPAR Commission, 1998). It is given by:

$$
C F=\frac{1}{N} \sum_{n=1}^{N} \frac{\left|D_{n}-M_{n}\right|}{\sigma_{D}}
$$

where $\mathrm{N}$ is the total number of observations, $\mathrm{n}$ is the $\mathrm{n}^{\text {th }}$ comparison, $D$ is the observed value, $M$ is the model value and

$$
\sigma_{D}=\sqrt{\frac{1}{N} \sum_{n=1}^{N}\left(D_{n}-\bar{D}\right)^{2}}
$$

$\sigma_{D}$ is the standard deviation of the observations. $\bar{D}$ denotes the mean of observations. The performance criteria used here are CF $<1$ very good, 1-2 good, 2-3 reasonable, $>3$ poor (Allen et al., 2007; Radach and Moll, 2006). 
Table 1. A Description of The Observation Data Set.

\begin{tabular}{|c|c|c|c|}
\hline Mooring Depth & Instrument \& Variables & Time & Annotation \\
\hline $\begin{array}{l}\text { B1 mooring } \\
\text { Depth = } 33 \mathrm{~m}\end{array}$ & $\begin{array}{l}\text { ADCP: } \\
\text { Zonal current } \\
\text { Meridional current }\end{array}$ & $\begin{array}{l}\text { 28-Apr-2013 to } 28- \\
\text { Apr-2014 }\end{array}$ & $\begin{array}{l}\text { The hourly time interval, } 15 \text { layers } \\
\text { with } 2 \mathrm{~m} \text { interval from the bottom }\end{array}$ \\
\hline $\begin{array}{l}\text { B2 mooring } \\
\text { Depth }=42.5 \mathrm{~m}\end{array}$ & $\begin{array}{l}\frac{\mathrm{ADCP}:}{\text { Zonal current }} \\
\text { Meridional current }\end{array}$ & $\begin{array}{l}\text { 03-Jul-2013 to } 26 \text { - } \\
\text { Apr-2014 }\end{array}$ & $\begin{array}{l}30 \text { minutes time interval, } 20 \text { layers } \\
\text { with } 2 \mathrm{~m} \text { interval from the bottom }\end{array}$ \\
\hline $\begin{array}{l}\text { B3 mooring } \\
\text { Depth }=41.6 \mathrm{~m}\end{array}$ & $\begin{array}{l}\text { ADCP: } \\
\text { Zonal current } \\
\text { Meridional current } \\
\text { Temperature }\end{array}$ & $\begin{array}{l}\text { 06-Jul-2013 to } 24- \\
\text { Apr-2014 }\end{array}$ & $\begin{array}{l}20 \text { minutes time interval, } 17 \text { layers } \\
\text { with } 2 \mathrm{~m} \text { interval from the bottom. } \\
\text { For temperature, only one layer } \\
\text { located at the bottom. }\end{array}$ \\
\hline $\begin{array}{l}\text { B4 mooring } \\
\text { Depth }=33.6 \mathrm{~m}\end{array}$ & $\begin{array}{l}\text { ADCP: } \\
\text { Zonal current } \\
\text { Meridional current }\end{array}$ & $\begin{array}{l}\text { 05-Jul-2013 to } 24- \\
\text { Apr-2014 }\end{array}$ & $\begin{array}{l}20 \text { minutes time interval, } 13 \text { layers } \\
\text { with } 2 \mathrm{~m} \text { interval from the bottom. }\end{array}$ \\
\hline
\end{tabular}

Table 1 gives information on observed variables that are used in this study. Although all data is coming from the same observation, the length of each time-series data can differ. It depends on the instrument.

The current profiles data were obtained from all ADCP covers 28 April 2013 to 24 April 2014. This period is a compromise for all ADCP recorded data, while each ADCP has different times in measurement, and 6 July 2013 to 11 June 2015 period is intersection time. The vertical bin sizes of ADCP measurements are 2 $\mathrm{m}$ for all current observations. Due to a problem caused by surface reflection contamination of the ADCP, the uppermost layers data are replaced with the values linearly extrapolated from underneath layers.

Used bathymetric data were obtained from ETOPO1 global bathymetry. The resolution of ETOPO1 data is $1 / 60^{\circ}$. Interpolation and extrapolation are performed to ADCP current profiles data to provide current data in straight sections. For section 1, two ADCP data in Gaspar strait are used in interpolation and extrapolation, while for section 2, two ADCP data in Karimata strait were used.

\section{Results and Discussion}

Ocean velocities validation was performed by comparing the magnitude of daily and depthaveraged current components (zonal and meridional) from model and observation. In this work, the nearest velocities model grid position to mooring location is used. Figure 2 shows the depth of daily average velocities comparison for four mooring stations.

The magnitudes of the zonal and meridional model velocities are weaker than observations, which have good performance, referred to as cost function (Allen et al., 2007; Radach and Moll, 2006). However, the model's velocities trends are generally following the observed velocities variations (see Fig. 2). Significantly, the B1 (Fig. 2.a) and B4 moorings (Fig. 2.g) show weak model values. It is understandable considering that $\mathrm{B} 1$ and $\mathrm{B} 4$ moorings are located in a narrow strait (Gaspar Strait), near the coasts. The model grid resolution is not sufficient enough to correctly reproduce the physical processes involved in such areas. The effect is particularly evident for the zonal components.

On the contrary, B2 and B3 moorings show comparable magnitude to the two zonal and meridional components observations. The B2 and B3 moorings are located in Karimata Strait, which wider than Gaspar Strait. As mentioned in Ffield and Robertson (2008), model errors are mainly due to topography, stratification, resolution, and tidal forcing.

The comparison between $\mathrm{V} 1.0$ and $\mathrm{V} 1.1$ versions of the model indicates very similar results in this region. The bathymetry changes in V1.1 is not significantly impacted the model velocities in Karimata Strait. A high-frequency velocities comparison has also been made. In this part, hourly surface velocities from the INDESO v1.1 model have been compared to hourly ADCP recorded surface velocities. A comparison of spectrum analysis is performed on hourly surface velocities to reveal signal variability (Fig. 3). Plots in Figure 3 show the spectrum versus period (hours/cycle), both for zonal and meridional velocities components.

Spectrum analysis of surface current shows model velocities have the same peaks as observations. Coincident peaks around 12- and 24-hours periods indicate that the diurnal and semi-diurnal tides are the dominant signal of variability in Karimata Strait. In B3 and B4 moorings positions, the model is in good agreement with observations for long periods. But in general, especially for low periods, observed velocities have higher spectral density values, which means the model can not able represent the high-frequency current variations. These differences in spectrum density can also be interpreted as underestimating the model's existing energy compared to the observations. 

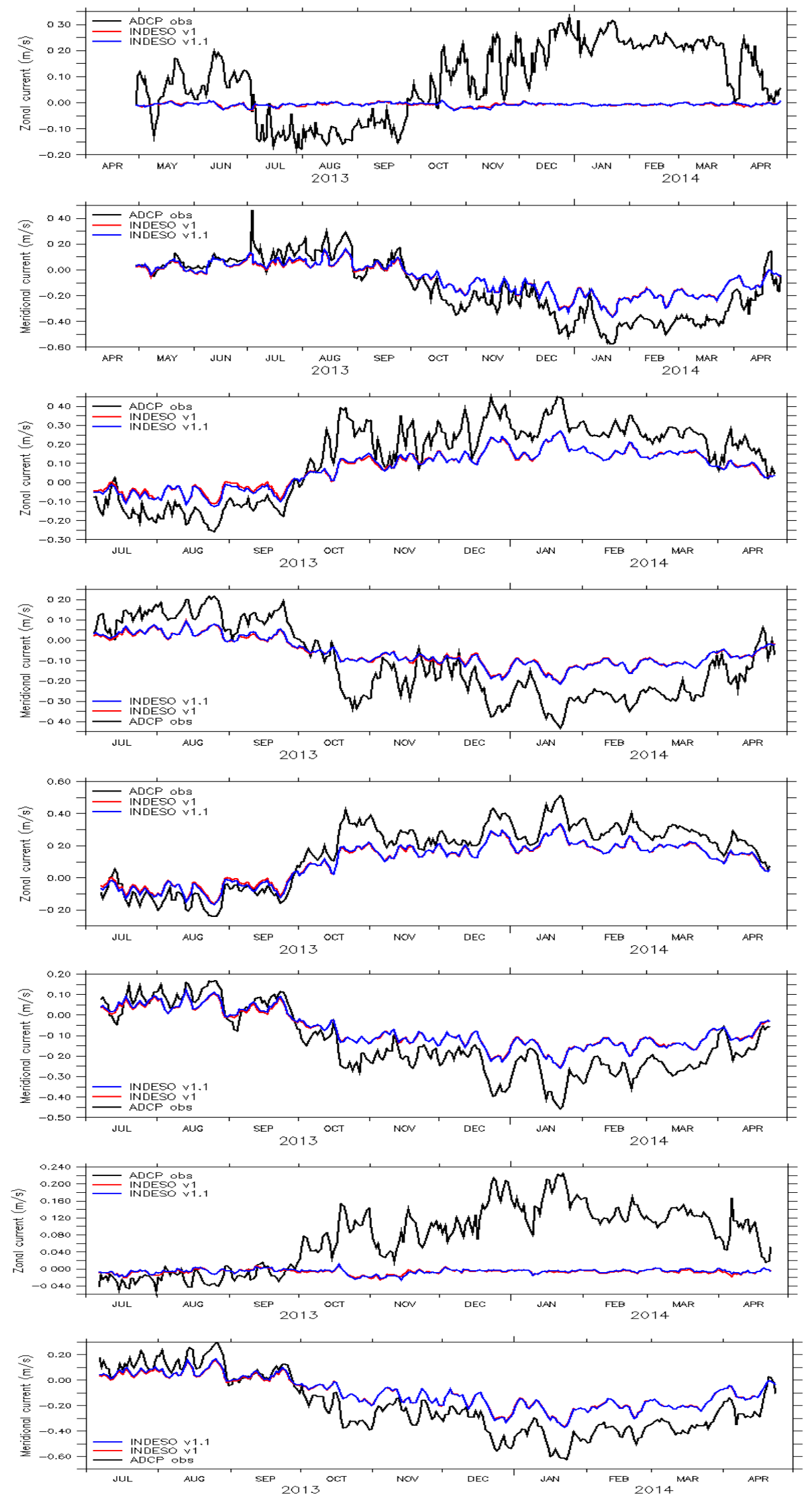

Figure 2. Time series plots of depth daily average current component zonal and meridional for B1 Mooring ( $a$ and b), B2 Mooring (c and d), B3 Mooring (e and f), and B4 Mooring ( $g$ and $h$ ) 


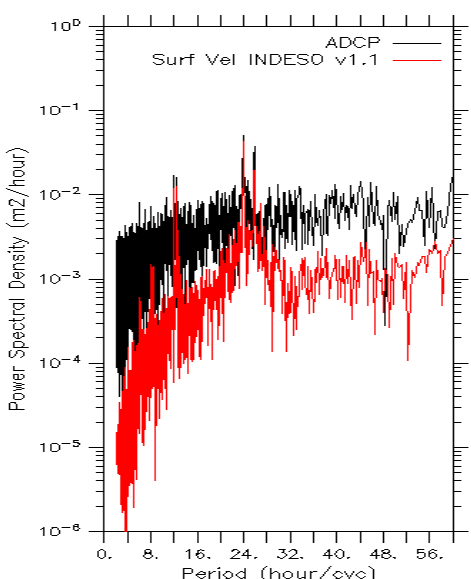

(a)
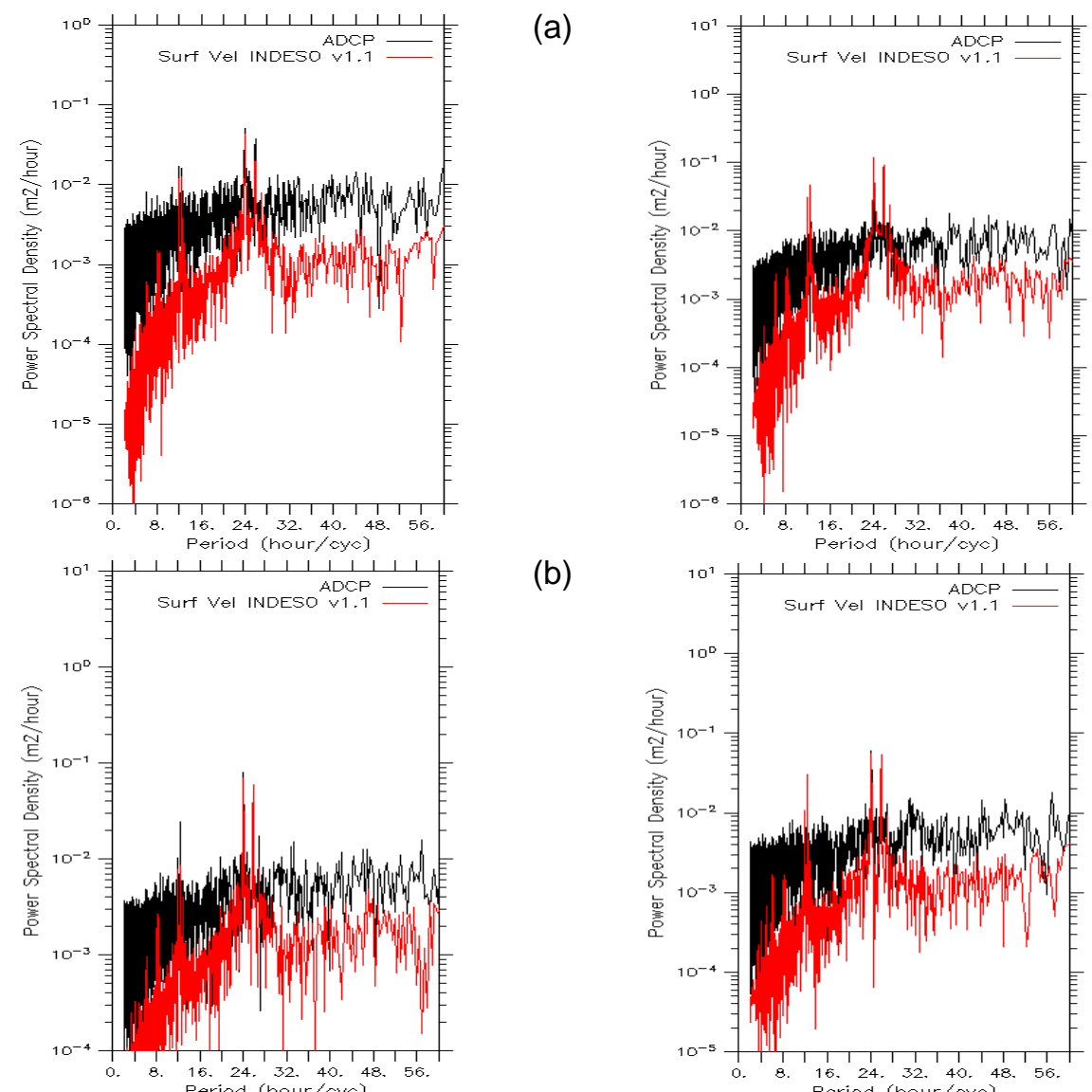

(b)
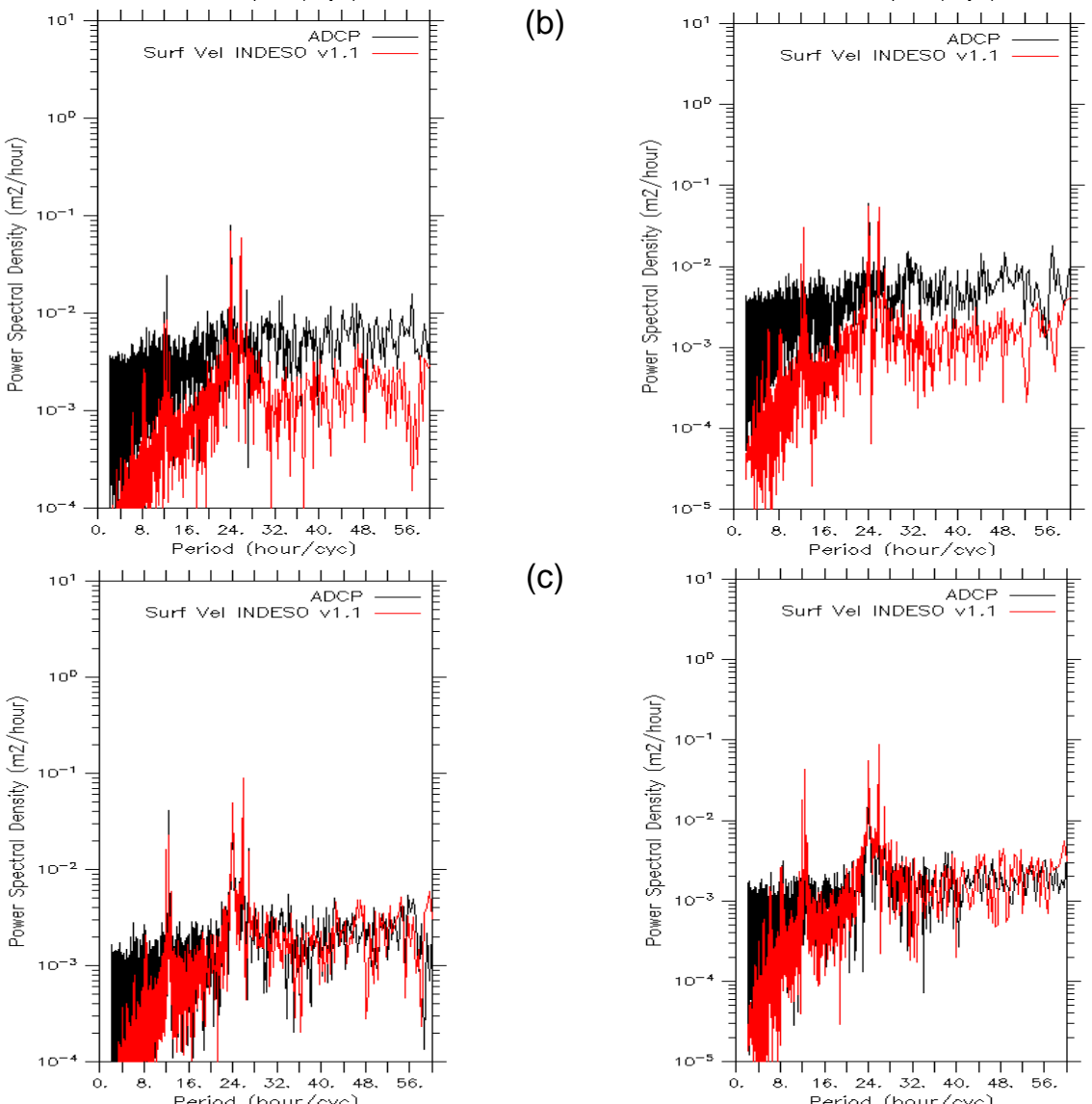

(c)
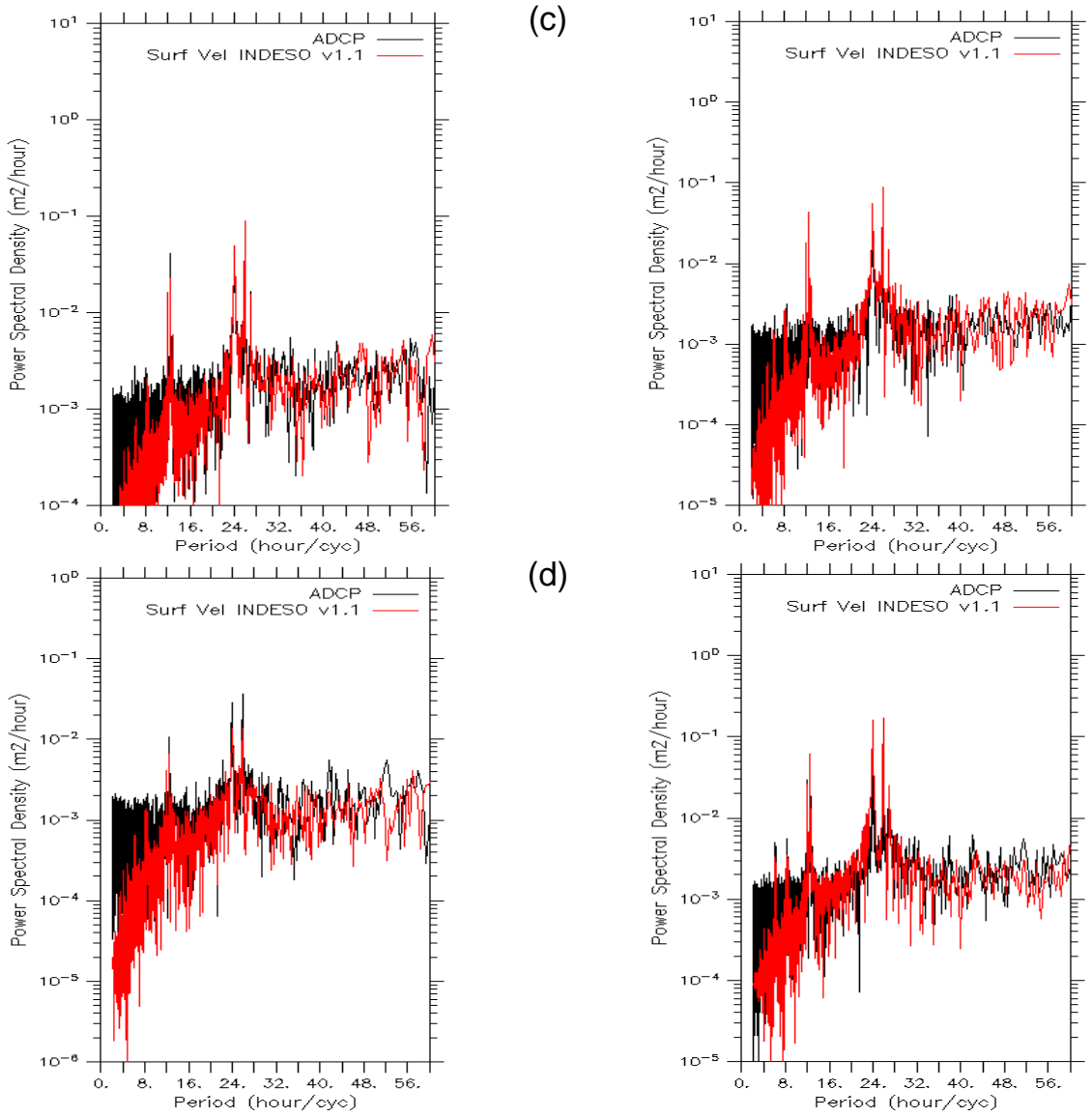

(d)

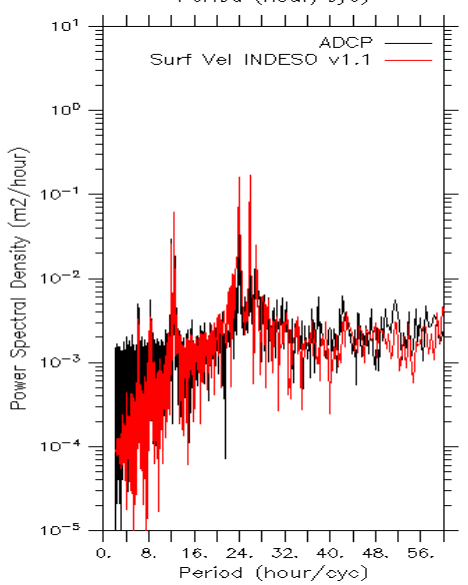

Figure 3. The spectrum versus period (hours/cycle), both for zonal (left) and meridional (right) velocities components. (a) B1 Mooring, (b) B2 Mooring (c) B3 Mooring, and (d) B4 Mooring locations. 


\section{Conclusions}

In the Karimata Strait, the model simulated lower current velocities than reality speeds but can reproduce seasonal signals. In the Gaspar Strait, the west side of Karimata Strait, current zonal rates are much smaller than observations. The difference between the model and observations could be because the model's grid resolution is too coarse for Karimata Strait, especially in the Gaspar Strait part. The model remarkably well simulates the high frequency (hourly) variability currents, and spectrum analysis results show it. It is concluded from the validation results that the model gives a reasonably fair comparison with the in-situ data, especially for seasonally signals. Perhaps with some improvements, such as sensitivity experiments and simulates in a finer grid, the model can produce more accurate results.

\section{Data Availability}

The INDO12 files and ADCP data used in the present paper are available upon request (please contact bpol@kkp.go.id). ETOPO1 data is available at:

https://www.ngdc.noaa.gov/mgg/global/global.ht ml.

\section{Acknowledgments}

This article's data model is a contribution from the Institute for Marine Research and Observation in the Space Oceanography Infrastructure Development program [INDESO]. Observation data is a contribution from the SITE Program sponsored by the Institute for Marine Research and Observation-Indonesia Budget Fund (DIPA IMRO) in collaboration with the First Institute of Oceanography-China and the Lamont-Doherty Earth Observatory [LDEO] USA.

\section{References}

Allen, J.I., Holt, J.S., Blackford, J., Proctor, J. 2007. Error quantification of a highresolution coupled hydrodynamic ecosystem coastal-ocean model: Part 2. Chlorophyll-a, nutrients and SPM. Journal of Marine Systems 68 (2007) 381 - 404. doi:10.1016/j.jmarsys.2007.01.005

Fang, G., Wang, Y., Wei, Z., Fang, Y., Qiao, F., $\mathrm{Hu}, \mathrm{X} .2009$. Interocean circulation and heat and freshwater budgets of the South China Sea based on a numerical model. Dyn. Atmos. Oceans 47, 55-72. http://dx.doi.org/10.1016/i.dynatmoce.2008 .09 .003 .

Fang, G., Susanto, R.D., Wirasantosa, S., Qiao, F., Supangat, A., Fan, B., Wei, Z., Sulistiyo, B., Li, S. 2010. Volume, heat, and freshwater transports from the South China Sea to Indonesian seas in the boreal winter of 2007-2008. Journal of Geophysical Research, Vol. 115, C12020, doi:10.1029/2010JC006225, 2010.

Ffield, A., Robertson, R. 2008. Temperature fine structure in the Indonesian Seas, J. Geophys. Res., 113, C09009, doi:10.1029/2006JC003864, 2008.

He, Z., Feng, M., Wang, D., Slawinski, D. 2015. Contribution of the Karimata Strait transport to the Indonesian Throughflow as seen from a data assimilation model. Continental Shelf Research 92. (2015) 16-22. DOI: http://dx.doi.org/10.1016/j.csr.2014.10.007.

Lebedev, K. V., and Yaremchuk, M. I. 2000. A diagnostic study of the Indonesian Throughflow, J. Geophys. Res., 105(C5), 11,243-11,258.

Doi:10.1029/2000JC900015.

Metzger, E. J., and Hurlburt, H.E. 1996. Coupled dynamics of the South China Sea, the Sulu Sea, and the Pacific Ocean, J. Geophys. Res., 101(C5), 12,331-12,352, doi:10.1029/95JC03861.

OSPAR Commission, 1998. Report of the Modelling Workshop on Eutrophication Issues. 5-8 November 1996. Den Haag, The Netherlands. OSPAR Report, $86 \mathrm{pp}$.

Radach, G., Moll, A., 2006. Review of threedimensional ecological modelling related to the North Sea shelf system. Part II: model validation and data needs. Oceanog. Mar. Biol. 44, 1-60 (An Annual Review).

Tozuka, T., Qu, T., Masumoto, Y., Yamagata, T. 2009. Impacts of the South China Sea Throughflow on seasonal and interannual variations of the Indonesian Throughflow. Dyn. Atmos. Oceans 47, 73-85. http://dx.doi.org/10.1016/j. dynatmoce.2008.09.001.

Tranchant, B., Reffray, G., Greiner, E., Nugroho, D., Koch-Larrouy, A., Gaspar, P. 2016. Evaluation of an operational ocean model configuration at $1 / 12^{\circ}$ spatial resolution for the Indonesian seas (NEMO2.3/INDO12) Part 1: Ocean physics. Geosci. Model Dev., 9, 1037-1064, 2016. doi:10.5194/gmd-91037-2016. 
Wang, Y., Tan, W., Xu, T., Li, S., Susanto, R.D., Agustiadi, T., Trenggono, M., Wei, Z. 2019/. Seasonal variation of water transport through the Karimata Strait. Acta Oceanol. Sin., 2019, Vol. 38, No. 4, P. 47-57. DOI: https://doi.org/10.1007/s13131-018-1224-2

Wei, Z., Fang, G., Susanto, R.D., Adi, T.R., Fan, B., Setiawan, A., Li, S., Wang, Y., Gao, X. 2016. Tidal elevation, current, and energy flux in the area between the South China Sea and Java Sea. Ocean Sci., 12, 517531, 2016. doi:10.5194/os-12-517-2016
Wyrtki, Klaus. 1961. Physical oceanography of Southeast Asian waters, in NAGA Report: Scientific Results of Marine Investigations of the South China Sea and Gulf of Thailand, vol. 2, Scripps Inst. of Oceanogr., La Jolla, Calif.

Yaremchuk, M., McCreary, J., Yu, Z., and Furue, R. 2009. The South China Sea throughflow retrieved from climatological data. J. Phys. Oceanogr. 39, 753-767. 